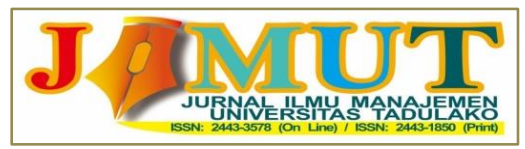

Vol. 7, No 3, Juli 2021, 300-309

\title{
IMPLIKASI KECERDASAN EMOSIONAL DAN MOTIVASI TERHADAP KINERJA KARYAWAN PT PALU GOLDEN HOTEL
}

\author{
William Admajaya Antolis \\ Idris \\ Yoberth Kornelius \\ Program Studi S1 Manajemen, Fakultas Ekonomi dan Bisnis, Universitas Tadulako \\ Email : williamadmajayaantolis@gmail; azis_idris@yahoo.com; yoberthkornelius@yahoo.com
}

\begin{abstract}
This study aims to determine and analyze the Implications of Emotional Intelligence and Motivation on Performance of employees at PT Palu Golden Hotel. This study uses descriptive quantitative. The population in this study were all employees at PT Palu Golden Hotel which numbered 49 people. This study uses was multiple linear regression. Based on the result of multiple linear regression analysis it can be concluded that Implications of Emotional Intelligence and Motivation influence simultaniously and significantly on the Performance of employees at PT Palu Golden Hotel which value of significantly 0,000 <0,05. Based on analysis result that Emotional Intelligence has a partial and significant effect on Performance employees at PT Palu Golden Hotel which value of significantly $0,000<0,05$. Motivation has a partial and significant effect on Performance employees at PT Palu Golden Hotel which value of significantly 0,00 0<0,05.
\end{abstract}

Keywords: Emotional Intelligence, Motivation, Performance.

ABSTRAK

Penelitian ini bertujuan agar dapat mengetahui dan menganalisis Implikasi Kecerdasan Emosional dan Motivasi terhadap kirneja karyawan pada PT Palu Golden Hotel. Penelitian ini termasuk pada penelitian deskriptif kuantitatif. Populasinya adalah keseluruhan Karyawan pada PT Makassar Raya Motor Cabang Palu. Teknik penarikan sampel adalah sensus dengan jumlah sampel 49 responden. Alat analisis yang digunakan adalah analisis regresi liner berganda. Berdasarkan hasil analisis regresi liner berganda didapatkan hasil bahwa variabel Kecerdasan Emosional dan Motivasi secara simultan berpengaruh signifikan terhadap Kinerja karyawan pada PT Palu Golden Hotel dengan nilai signifikan $0.000<0.05$. Hasil pengujian secara persial ditemukan bahwa variabel Kecerdasan Emosional memiliki pengaruh yang signifikan dengan nilai signifikansi $0.000<0.05$. Motivasi memiliki pengaruh secara parsial dengan nilai signifikansi $0,000<0,05$.

\section{Kata Kunci: Kecerdasan Emosional, Motivasi, Kinerja.}

\section{PENDAHULUAN}

Pengendalian emosi menjadi sangat penting dikarenakan emosi seseorang dapat mengganggu produktivitas kinerja karyawan, terutama pada bisnis perhotelan yang dimana bisnis perhotelan pada dominannya bergerak dibidang jasa, kecerdasan emosional yang dimiliki oleh setiap karyawan akan membantu mereka dalam melaksanakan tugas dan pekerjaan sehari-hari demi sebuah keberhasilan yang diimpikan. Mangkunegara (2016:44) bahwa Kecerdasan Emosi yang baik adalah mampu memahami diri dan orang lain secara benar, memiliki jati diri, kepribadian kedewasaan mental, tidak benci, tidak sakit hati, tidak dendam, tidak iri hati, tidak memiliki perasaan bersalah yang berlebihan, tidak cemas, tidak mudah marah, dan tidak mudah frustasi. Oleh karenanya dalam praktek kecerdasan emosional sangat perlu diperhatikan untuk lebih dimaksimalkan.

Motivasi memiliki peranan yang tidak kalah pentingnya dalam peningkatan kinerja karyawan, motivasi mempunyai peran agar setiap karyawan terdorong untuk melakukan suatu kegiatan dalam 
mencapai tujuan perusahaan. Motivasi yang tinggi akan tercermin dari rasa tanggung jawab dan gairah untuk bekerja yang tinggi sehingga terjadilah suatu keinginan dalam bekerja dengan giat dan juga rasa ingin memberikan sesuatu yang terbaik bagi pekerjaannya. Menurut Mathis \& Jackson dalam Bangun (2012 : 312) mengungkapkan bahwa, motivasi merupakan keinginan pada seseorang yang menyebabkan orang tersebut melakukan suatu tindakan untuk mencapai tujuan.

Kinerja (Performance) sering diartikan sebagai hasil kerja yang mana menurut Bangun (2012) Kinerja adalah hasil pekerjaan yang dicapai seseorang berdasarkan persyaratan-persyaratan pekerjaan (job requirement). Hasil pekerjaan seorang karyawan dapat diukur melalui jumlah, kualitas, ketepatan waktu pekerjaan, kehadiran dan kemampuan bekerjasama.

Hotel adalah sebuah bangunan perusahaan yang menyediakan banyak sekali fasilitas di antaranya adalah jasa dan makanan bagi para pengunjungnya yang datang. PT Palu Golden Hotel dituntut harus mampu meningkatkan kinerja karyawannya sehingga tetap bekerja secara profesional. Tenaga kerja yang profesional menjadi salah satu faktor keberhasilan dalam bersaing di dunia perhotelan, tenaga kerja yang profesional haruslah bekerja dengan standar operasional prosedur (SOP) yang dimana para pekerja dituntun bisa bekerja keras dan disiplin. Aspek yang mendukung penelitian ini ingin melihat Implikasi Kecerdasan Emosional dan Motivasi terhadap Kinerja karyawan PT Palu Golden Hotel sebagai lokasi penelitian adalah kurangnnya pengendalian emosi ketika karyawan di berikan tugas kerja yang berlebihan yang berakibat pada kesalah pahaman diantara karyawan saat bekerja, peningkatan stres kerja, dan penurunan kinerja, selain itu beberapa karyawan masi merasakan rasa jenuh dan masih takut akibat keadian gampa dan tsunami 28 september 2019 yang lalu, walaupun demikian mereka tetap harus bekerja untuk kelangsungan hidup keluarga mereka. Penelitian ini menggunakan menggunakan metode sensus dalam pengumpulan datanya.

\section{KAJIAN LITERATURE}

\section{Kecerdasan Emosional}

Goleman (1997) mengatakan bahwa koordinasi suasana hati merupakan inti dari hubungan sosial yang baik. Apabila seseorang pandai dalam menyesuaikan diri dengan suasana hati individu mereka yang lain atau dapat berempati, orang tersebut akan lebih mudah menyesuaikan diri dalam pergaulan sosial serta lingkungannya dan memiliki tingkat emosionalitas yang baik, kecerdasan emosional merupakan kemampuan diri seseorang dalam menggerakan hasrat dan juga melindungi diri dalam menghadapi beban stress berlebihan dan rasa senang yang berlebihan agar tidak mempengaruhi kemampuan berpikir, bertindak, mengambil keputusan, dan berinteraksi. Hal tersebut dapatlah mempengaruhi kinerja dari seseorang dalam bekerja terutama pada kinerja karyawan PT Palu Golden Hotel.

Goleman (2007 : 58) mencetuskan lima wilayah atau dimensi utama kecerdasan emosional, yaitu: (1) Mengenali emosi diri, merupakan dasar kecerdasan emosional. Kemampuan untuk memantau perasaan dari waktu kewaktu merupakan hal yang penting bagi wawasan psikologis dan pemahaman diri atau pengenalan diri, Ketidakmampuan untuk mencermati perasaan kita yang sesungguhnya membuat kita dalam kekuasaan perasaan dan kekosongan diri. (2) Mengelola emosi, menangani suatu perasaan agar bisa terungkap dengan benar adalah kecakapan yang bergantung pada kesadaran diri. Orang-orang yang pintar dalam mengelola emosi akan dapat bangkit dengan cepat dari kemerosotan dan kejatuhan dalam kehidupan. (3) Memotivasi diri, menata emosi sebagai alat untuk mencapai tujuan adalah hal yang sangat penting dan erat kaitannya dengan memotivasi diri dan dapat dilakukan dengan memberi perhatian pada diri, kendali diri, menguasai diri, menahan diri terhadap kepuasan, mengendalikan dorongan hati, serta menyenangkan diri yang 
tidak berlebihan. (4) Mengenali emosi orang lain atau empati salah satu keterampilan dalam bergaul atau kecakapan sosial. Orang-orang empatik lebih mampu menangkap isyarat apa-apa yang dibutuhkan atau dikehendaki orang lain, dan dapat menangkap sinyal-sinyal sosial yang tersembunyi. (5) Membina hubungan, seni membina hubungan sebagian besar merupakan keterampilan dalam mengelola emosi orang lain juga kecakapan sosial. Orang-orang yang hebat dalam hal ini akan sukses dibidang manapun dan dapat mengendalikan pergaulan yang mulus dengan orang lain, dengan kata lain mereka adalah bintang-bintang dalam pergaulan. Setyaningrum dkk(2000) mendeskripsikan Kecerdasan Emosional sebagai kemampuan untuk merasakan kejujuran hati yang menjadi pusat prinsip untuk mampu memberikan rasa aman pedoman, kekuatan seta kebijaksanaan.

\section{Motivasi}

Motivasi merupakan kondisi atau keadaan dimana seseorang mempunyai alasan atau keinginan sehingga mau melakukan atau mengambil sebuah tindakan yang akan dihadapinya. Dalam George \& Jones (2005), mengartikan motivasi adalah semangat kerja yang ada pada karyawan agar tetap bekerja untuk mencapai tujuan tertentu.Sunyoto (2012:17-18).

Abaraham Maslow mengemukakan sebuah teori motivasi dalam buku Hasibuan (2003), yang dimana motivasi adalah sebuah pemicu yang sifatnya mendorong keingan seseorang untuk bekerja pada diri seorang untuk memenuhi kebutuhannya. Teori ini menfokuskan pada beberapa faktor dalam diri seseorang, yang mengarahkan, menggerakan, mendukung, dan menghentikan prikau buruk seseorang. Abraham Maslow menyusun teori ini dan menghipotesiskan bahwa dalam diri setiap manusia memiliki lima tingkatan kebutuhan, yaitu (1) Kebutuhan Fisiologis, termasuk didalamnya rasa lapar, rasa haus, rasa ingin memiliki tempat berteduh atau tampat tinggal, seks, dan kebutuhan badaniah lainnya. Pada prakteknya kebutuhan fisiologis lebih difokuskan pada pemberian insentif yang layak pada karyawan seperti gaji, bonus, uang makan, fasilitas tempat tinggal, uang transportasi, dan lain sebagainya.(2) Kebutuhan rasa aman, termasuk didalamnya keamanan dan juga perlindungan pada gangguan fisik serta emosional dalam bekerja maupun di luar pekerjaan. Kebutuhan rasa aman lebih mengarah pada fasilitas keselamatan kerja dan keamanan contohnya, dana pension, jaminan sosial tenaga kerja, tunjangan kesehatan, perlengkapan keselamatan kerja, dan asuransi kesehatan. (3) Kebutuhan sosial, termasuk didalamnya rasa kasih sayang, rasa penerimaan oleh lingkungan masyarakat, dan juga rasa keinginan untuk hidup berkelompok, menjalin hubungan kerja yang harmonis, serta kebutuhan untuk mencintai dan dicintai. Kebutuhan sosial ini menitik beratkan pada interaksi sosial dengan orang lain. (4) Kebutuhan penghargaan, termasuk didalamnya harga diri seseorang, kemandirian, keberhasilan, status, pengakuan oleh orang lain, dan perhatian dari orang sekitar termasuk lingkungan kerja baik itu pimpinan maupun sesama karyawan lainnya. Kebutuhan ini diberikan berdasarkan kemampuan. (5) Kebutuhan akan aktualisasi diri, termasuk dalam nya kemampuan yang dimiliki seseorang, keinginan atau kemampuan untuk berkembang, keinginan atau kemampuan seseorang untuk mencapai sesuatu, kemampuan seseorang dalam mencukupi diri sendiri. Kebutuhan ini dapat dilihat dari karyawan yang mengerahkan kecakapannya, kemampuan, keterampilan, dan potensinya. Sehingga dalam pemenuhannya perusahaan dapat menyelenggarakan pendidikan dan pelatihan. 


\section{Kinerja}

Menurut Bangun (2012:231) menyatakan bahwa kinerja (Performance) adalah suatu hasil kerja yang dihasilkan oleh seseorang melalui proses berdasarkan persyaratan pekerjaan (job requiretment). Persyaratan pekerjaan diterapkan agar kinerja karyawan tetap konstan dan terpenuhinya tujuan perusahaan, selain itu dalam bukunya Samsudin (2006:159) memberikan pengertian kinerja adalah tingkatan pekerjaan yang telah dicapai oleh karyawan dengan kemampuannya melalui batasan pekerjaan yang sudah ditetapkan oleh perusahaan guna mencapai tujuan organisasi. Nawawi (2005:234) memberikan pengertian kinerja sebagai hasil dari pelaksanaan suatu pekerjaan. Yang hasil kerjanya merupakan suatu prilaku seseorang atau perbuatan secara tidak langsung maupun langsung bisa diperhatikan oleh orang lain.

Byars dan Rue (2008:216) kinerja diartikan sebagai hasil dari suatu usaha seseorang yang dalam pencapaiannya dilakukan dengan adanya kemampuan dan perbuatan pada situasi tertentu. Byars merangkum teori kinerjanya menjadi tiga bagian yaitu usaha, kemampuan, dan presepsi tugas, diskrepsikan sebagai berikut : (1) Usaha merupakan hasil dari motivasi yang memperlihatkan jumlah energi (mental atau fisik) yang dikeluarkan oleh individu dalam pelaksanaan tugas. (2) Kemampuan merupakan ciri khas atau keahlian seseorang yang digunakan dalam melakukan suatu pekerjaan. Kemampuan ini pada umumnya tidak dapat dipengaruhi secara langsung dalam jangka yang pendek. (3) Presepsi tugas merupakan penunjuk yang dimana dalam pekerjaannya individu percaya bahwa mereka dapat mewujudkan usaha-usaha mereka.

Keberhasilan suatu organisasi dengan berbagai ragam kinerja tergantung kepada kinerja seluruh anggota organisasi itu sendiri. Menurut Mangkunergara (2005:67-68) mengemukakan beberapa faktor yang mempengaruhi kinerja seseorang ialah : (1) Faktor kemampuan, pada umumnya kemampuan ini dibagi menjadi dua bagian yaitu kemampuan potensi (IQ) dan kemampuan reality (knowledge dan skill). (2) Faktor motivasi, terbentuknya motivasi berdasarkan sikap karyawan dalam melengkapi situasi kerja.

Dari pernyataan diatas bahwa kecerdasan emosional dan motivasi berpengaruh terhadap kinerja, apabila dalam mengelola emosi di dalam melakukan tugas dan penyelesaian pekerjaan tidak akan efektif, jika hanya menggunakan keterampilan dan kecerdasan intelektual saja tetapi haruslah lebih mendalami diri agar bekerja dari dalam hati dengan penuh keiklasan dan mampu menguasai, mengelola diri sendiri serta membina hubungan dengan orang lain dan menjaga agar beban stres tidak melumpuhkan kemampuan karyawan itu sendiri. Selain itu motivasi haruslah diberikan dengan baik agar dapat memberikan semangat yang dapat menghasilkan kinerja yang baik dari karyawan. Oleh karena itu berdasarkan pernyataan tersebut jelaslah bahwa kecerdasan emosional dan motivasi berpengaruh terhadap kinerja. 


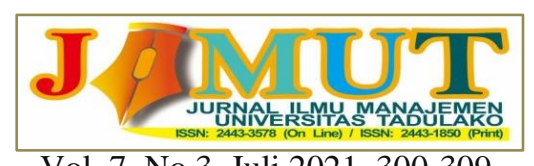

Vol. 7, No 3, Juli 2021, 300-309

\section{Kecerdasan Emosional (X1) \\ 1. Pengenalan Diri \\ 2. Pengendalian Diri \\ 3. Motivasi \\ 4. Empati \\ 5. Keterampilan Sosial}

(Sumber : Goleman, 2007)

\section{Motivasi Kerja (X2)}

1. Kebutuhan Fisiologis

2. Rasa Aman

3. Kepemilikan Sosial

4. Penghargaan Diri

5. Aktualisasi Diri

(Sumber : Maslow dalam

Hasibuan, 2003)

\section{Kinerja (Y)}

1. Usaha

2. Kemapuan

3. Presepsi Tugas

(Sumber : Byars dan

Rue, 2008)

Sumber : Data diolah tahun 2018

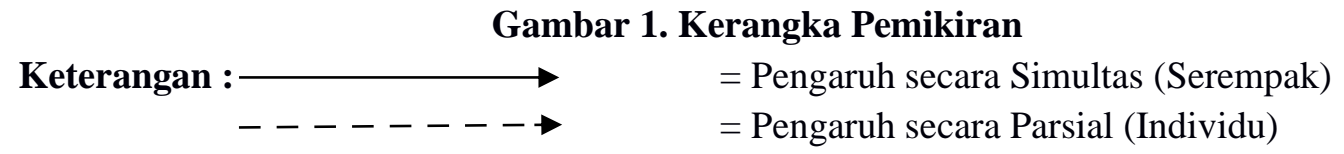

Berdasarkan kajian teori, penelitian terdahulu dan kerangka pemikiran maka dapat dikemukakan hipotesis penelitian sebagai berikut: $\left(\mathrm{H}_{1}\right)$ Kecerdasan Emosional dan Motivasi berpengaruh serempak terhadap Kinerja karyawan PT Palu Golden Hotel, $\left(\mathrm{H}_{2}\right)$ Kecerdasan Emosional berpengaruh terhadap Kinerja karyawan PT Palu Golden Hotel, $\left(\mathrm{H}_{3}\right)$ Motivasi berpengaruh terhadap Kinerja karyawan PT Palu Golden Hotel.

\section{METODE PENELITIAN}

Dalam penelitian ini peneliti menggunakan kuantitatif, karena penelitian ini menggunakan data dari PT Palu Golden Hotel untuk dianalisis implikasi antar variabel yang dinyatakan dalam bentuk angka. Penelitian ini termasuk juga penelitian asosiatif kausal karena dalam penelitian ini mempunyai tujuan meneliti dan mengetahui sebab akibat antara variabel independen yakni kecerdasan emosional dan motivasi terhadap variabel dependen yaitu kinerja.

Sumber data berasal dari data Primer dan Sekunder dimana, (1) Data primer adalah data yang diperoleh pertama kali dan dikumpulkan secara langsung oleh peneliti dari sumber utama pada lokasi penelitian dalam hal ini para karyawan yang masuk dalam kriteria sampel di PT Palu Golden Hotel dengan cara observasi lapangan, wawancara, dan kuesioner mengenai kecerdasan emosional dan motivasi terhadap kinerja karyawan. (2) Data sekunder adalah sumber data yang dimana peneliti tidak terlibat langsung dalam pengumpulannya dan sudah ada pada PT Palu Golden Hotel seperti, dokumen, buku atau literatur yang berhubungan dengan penelitian, seperti sejarah 
perusahaan, jumlah pengunjung, jumlah karyawan, dan struktur organisasi. Populasi dalam penelitian ini adalah seluruh karyawan PT Palu Golden Hotel.

Jumlah karyawan yang berada pada PT Palu Golden Hotel sejumlah 49 orang yang tercatat masih aktif. Teknik pengambilan sampel pada penelitian ini yaitu dengan menggunakan teknik sampling jenuh atau biasa disebut sensus, dimana semua anggota populasi dijadikan sebagai sampel dikarenakan semua populasi memiliki kriteria yang dibutuhkan dan jumlah popuasinya tidak lebih dari 100.

Teknik pengumpulan data dalam penelitian ini sebagai berikut : (1) Observasi merupakan metode yang dilakukan peneliti dengan melakukan pengamatan langsung pada objek penelitian mengenai variabel-variabel yang diteliti pada saat jam kerja. Dalam hal ini yaitu karyawan pada PT Palu Golden Hotel. (2)Wawancara adalah metode pengumpulan data yang dilakukan oleh peneliti dengan melakukan komunikasi serta tanya jawab langsung kepada beberapa karyawan PT Palu Golden Hotel dengan maksud memperoleh informasi dari responden yang lebih mendalam. (3) Teknik kuesioner adalah metode yang digunakan peneliti dalam pengumpulan data dilakukan dengan cara memberikan kumpulan pertanyaan yang di buat berdasarkan panduan kuesioner kepada responden untuk dijawab dan diisi oleh seluruh karyawan pada PT Palu Golden Hotel selaku responden. Peneliti sangat mengharapkan kejujuran dari setiap individu dalam pengisian kuesioner tersebut. (4) Studi dokumenetasi yang dilakukan oleh peneliti yaitu pengumpulan data dengan melihat arsip-arsip, dokumen-dokumen, dan literatur yang erat kaitannya dengan penelitian pada PT Palu Golden Hotel.

Indikator-indikator dari masing-masing variabel akan diukur dengan menggunakan daftar pertanyaan/pernyataan atau kuesioner (angket). Skala pengukuran yang digunakan dalam kuesioner pada penelitian ini adalah skala Likert.. Penentuan nilai skor dari alternatif pertanyaan-pertanyaan atau pernyataan-pernyataan yang diajukan sebagaimana Tabel 1. berikut:

Tabel 1. : Skor Atas Jawaban Pertanyaan Berdasarkan Skala Likert

\begin{tabular}{cc}
\hline Skala Likert & Skor \\
\hline Sangat Setuju (SS) & 5 \\
Setuju (S) & 4 \\
Netral (N) & 3 \\
Tidak Setuju (TS) & 2 \\
Sangat Tidak Setuju (STS) & 1 \\
\hline
\end{tabular}

Sumber : Sugiyono (2013)

Pengujian hipotesis dalam penelitian ini digunakan analisis kualitatif dengan memaparkan hasilhasil penelitian dilapangan secara deskriprif dan analisa kuantitatif dengan menggunakan angkaangka statistik melalui penggunaan alat analisis statistik Regresi Linear Berganda (Multiple Linear Regression).

Alasan menggunakan regresi linear berganda. karena variabel yang diteliti merupakan variabel yang sifat penelitiannya memiliki hubungan linear antara variabel yang dihipotesiskan. sehingga $Y$ dipengaruhi oleh variabel-variabel bebas X1.X2.X3 ......Xn. Sehingga rumus umum dari regresi berganda Sugiyono (2013:77) Sebagai berikut :

Keterangan :

$$
\mathbf{Y}=\mathbf{a}+\mathbf{b}_{1} \mathbf{X}_{1}+\mathbf{b}_{2} \mathbf{X}_{2}+\ldots .+\mathbf{b}_{\mathbf{n}} \mathbf{X}_{\mathbf{n}}+\boldsymbol{e}(1)
$$

$\mathrm{Y}$

A

$$
\begin{aligned}
& =\text { Kinerja } \\
& =\text { Konstanta }
\end{aligned}
$$




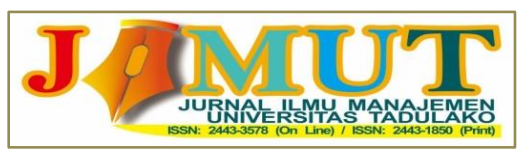

Vol. 7, No 3, Juli 2021, 300-309

$$
\begin{array}{ll}
\mathrm{b}_{1}-\mathrm{b}_{2} & =\text { Parameter yang diukur } \\
\mathrm{X} 1 & =\text { Kecerdasan Emosional (EQ) } \\
\mathrm{X} 2 & =\text { Motivasi } \\
E & =\text { error / variabel pengganggu }
\end{array}
$$

Uji parsial (uji t) digunakan untuk membuktikan seberapa jauh pengaruh satu variabel independen secara individual dalam menerangkan varian variabel dependen Ghozali (2011:98). Hipotesis yang digunakan dalam pengujian ini adalah:

(1) Ho : Variabel-variabel bebas (Kecerdasan Emosional dan Motivasi) tidak mempunyai pengaruh yang signifikan terhadap variabel tingkat (Kinerja Karyawan).

(2) Ha : Variabel-variabel bebas (Kecerdasan Emosional dan Motivasi) mempunyai pengaruh yang signifikan terhadap variabel terikat (Kinerja Karyawan).

Dasar pengambilan keputusan Ghozali (2011:98). menggunakan angka probabilitas signifikan dengan tingkat signifikansi $95 \%(\mathrm{Q}=5 \%)$.

(1) Apabila probabilitas signifikansi > 0.05. maka Ho diterima dan Ha ditolak.

(2) Apabila probabilitas signifikansi $<0.05$. maka Ho ditolak dan Ha diterima.

Selain metode kaidah diatas dapat juga manggunakan ketentuan $t_{\text {tabel }}$ dimana apabila $t_{\text {hitung }}>$ $t_{\text {tabel }}$ maka uji tersebut menandakan bahwa variabel-variabel independen yang diteliti berpengaruh terhadap variabel dependen.

\section{HASIL DAN PEMBAHASAN}

Uji validitas instumen penelitian ini dilakukan pada Cameloan Hotel Palu dengan mengambil 20 responden. Menurut Solimun (2002:70), mengatakan bila koefisien korelasi antara skoor indikator dengan skor total seluruh indikator adalah positif dan lebih besar $0,3(\mathrm{r} \geq 0,3)$ maka instrumen tersebut dianggap valid. Instrumen yang dikembangkan dalam daftar pertanyaann akan dianggap reliabel apabila hasil yang dicapai dari sebuah alat ukur mempunyai tingginya tingkat konsistensi seiring berjalannya waktu. Menurut Solimun $(2002 ; 81)$ menyatakan bahwa suatu instrumen atau

\begin{tabular}{|c|c|c|c|c|}
\hline Variabel Penelitian & Dimensi & $\begin{array}{l}\text { Cronbach's } \\
\text { Alpa }\end{array}$ & $\begin{array}{l}\text { Alpha } \\
\text { Tolerance }\end{array}$ & Keterangan \\
\hline \multirow{5}{*}{$\begin{array}{l}\text { Kecerdasan } \\
\text { (X1) }\end{array}$} & Pengenalan Diri & 0.836 & 0.6 & Realibel \\
\hline & Pengendalian Diri & 0.806 & 0.6 & Realibel \\
\hline & Motivasi & 0.833 & 0.6 & Realibel \\
\hline & Empati & 0.861 & 0.6 & Realibel \\
\hline & Keterampilan Sosial & 0.872 & 0.6 & Realibel \\
\hline \multirow{4}{*}{ Motivasi (X2) } & Kebutuhan Fisiologis & 0.732 & 0.6 & Realibel \\
\hline & Kebutuhan Rasa Aman & 0.846 & 0.6 & Realibel \\
\hline & Kebutuhan Sosial & 0.753 & 0.6 & Realibel \\
\hline & Penghargaan Diri & 0.744 & 0.6 & Realibel \\
\hline
\end{tabular}
seluruh indikator dianggap sudah cukup reliabel apabila memiliki alpha cronbach lebih besar dari $0.6(\alpha \geq 0.6)$.

Tabel 2. Hasil Uji Reliabilitas Variabel Pelatihan 


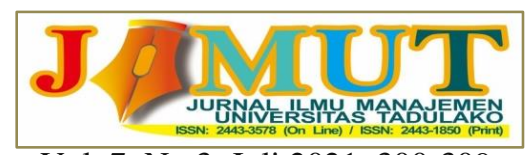

Vol. 7, No 3, Juli 2021, 300-309

\begin{tabular}{lllll} 
& Aktualisasi Diri & 0.764 & 0.6 & Realibel \\
\hline \multirow{3}{*}{ Kinerja (Y) } & Usaha & 0.827 & 0.6 & Realibel \\
& Kemampuan & 0.688 & 0.6 & Realibel \\
& Presepsi Tugas & 0.693 & 0.6 & Realibel \\
\hline
\end{tabular}

Sumber : Output SPSS For Windows Release 16.0, 2019

Tabel 2. diatas menyatakan bahwa kuesioner penelitian yang dipakai didalam penelitian semuanya reliabel. Ini buktikan dengan angka koefisien cronbach alpha $>0,60$ berarti memenuhi syarat minimum untuk dilakukan penelitian selanjutnya.

Tabel 4. Hasil Perhitungan Regresi Linear Berganda

\begin{tabular}{|c|c|c|c|c|c|}
\hline \multirow[t]{2}{*}{ Model } & \multicolumn{2}{|c|}{$\begin{array}{l}\text { Unstandardized } \\
\text { Coefficients }\end{array}$} & $\begin{array}{l}\text { Standardized } \\
\text { Coefficients }\end{array}$ & \multirow[t]{2}{*}{$\mathbf{T}$} & \multirow[t]{2}{*}{ Sig. } \\
\hline & B & Std. Error & Beta & & \\
\hline (Constant) & 1.596 & 0.412 & & 3.872 & 0.000 \\
\hline $\begin{array}{l}\text { X1(Kecerdasan } \\
\text { Emosional) }\end{array}$ & 0.361 & 0.088 & 0.442 & 4.113 & 0.000 \\
\hline X2 (Motivasi) & 0.419 & 0.094 & 0.450 & 4.183 & 0.000 \\
\hline Multiple R & $=0,718^{\mathrm{a}}$ & & F- hitung & $=24.476$ & \\
\hline R Square $\left(\mathrm{R}^{2}\right)$ & $=0,516$ & & & & \\
\hline Adjusted R Square & $=0.494$ & & Sig. F & $=0,000^{\mathrm{a}}$ & \\
\hline
\end{tabular}

Sumber:Output SPSS For Windows Release 16.0, 2019

Berdasarkan nilai dari Tabel 4. di atas, maka persamaan regresi linear berganda dapat dirumuskan sebagai berikut:

$$
Y=1.596+0,361 X 1+0,419 X_{2}
$$

Berdasarkan persamaan diatas menyatakan bahwa variabel independen memberi pengaruh positif kepada variabel dependen. Menurut hasil analisis regresi linear berganda diatas dapat dilihat besarnya pengaruh hasil uji determinasi R square yakni 0,516 atau $51.6 \%$ jadi variabel X1 dan X2 memiliki pengaruh pada kepuasan kerja karyawan sebanyak 51.6\% dan variabel lain yang tidak diteliti didalam penelitian yang mempengaruhi sisanya.

\section{Tabel 5. Hasil Pengujian Secara Serempak (Uji F)}

\begin{tabular}{|c|c|c|c|c|c|}
\hline \multicolumn{6}{|c|}{ ANOVA $^{a}$} \\
\hline Model & $\begin{array}{l}\text { Sum } \\
\text { Squares }\end{array}$ & of $\mathrm{Df}$ & $\begin{array}{l}\text { Mean } \\
\text { Square }\end{array}$ & $\mathbf{F}$ & Sig. \\
\hline Regression & 2,896 & 2 & 1,448 & 24.476 &, $000^{\mathrm{b}}$ \\
\hline Residual & 2,721 & 46 &, 062 & & \\
\hline Total & 5,617 & 48 & & & \\
\hline
\end{tabular}

Sumber:Output SPSS For Windows Release 16.0, 2019

Berdasarkan tabel diatas angka signifikansi sebesar $0,000 \leq 0,05$ (nilai alpha) dan nilai $\mathrm{F}$ hitung sebesar 24,476 $\geq 3,15$ (nilai F-tabel). Maka hipotesis pertama pada penelitian ini dapat diterima karena terdapat pengaruh secara serempak pada variabel Kecerdasan Emosional $\left(\mathrm{X}_{1}\right)$ dan Motivasi $\left(\mathrm{X}_{2}\right)$ terhadap Kinerja Karyawan PT Palu Golden Hotel. 


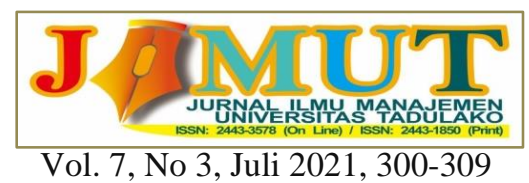

Tabel 6. Hasil Pengujian Secara Parsial (Uji t)

Coefficients $^{\mathrm{a}}$

\begin{tabular}{|c|c|c|c|c|c|}
\hline \multirow[t]{3}{*}{ Model } & \multirow{2}{*}{\multicolumn{2}{|c|}{$\begin{array}{l}\text { Unstandardized } \\
\text { Coefficients }\end{array}$}} & \multirow{3}{*}{$\begin{array}{l}\text { Standardized } \\
\text { Coefficients } \\
\text { Beta }\end{array}$} & \multirow[t]{3}{*}{$\mathrm{T}$} & \multirow[t]{3}{*}{ Sig. } \\
\hline & & & & & \\
\hline & $\mathrm{B}$ & Std. Error & & & \\
\hline (Constant) & 1,596 & ,412 & & 3,872 & ,000 \\
\hline Kecerdasan Emosional & ,361 & ,088 & ,442 & 4,113 &, 000 \\
\hline Motivasi & ,419 & , 100 & ,450 & 4,183 & ,000 \\
\hline
\end{tabular}

Sumber: Output SPSS For Windows Release 16.0, 2019

Berdasarkan pada hasil Tabel 6. tersebut dapat dijabarkan bahwa: (1)Kecerdasan Emosional berpengaruh terhadap Kinerja karyawan. Berdasarkan Tabel 6. hasil pengujian SPSS 16 diperoleh hasil angka signifikan sebesar 0,000. Angka 0,000 $<0,05$ (nilai alpha) dan t-hitung 4,113 $\geq 1,999$ (t- tabel) oleh karena itu Ha di terima dan menolak Ho. Hal ini berarti terdapat pengaruh antara variabel Kecerdasan Emosional $\left(\mathrm{X}_{1}\right)$ Kinerja Karyawan pada PT Palu Golden Hotel. Hipotesis kedua dapat diterima, (2) Motivasi memiliki pengaruh yang signifikan terhadap Kinerja karyawan. Berdasarkan Tabel 6., hasil pengujian SPSS 16 diperoleh angka signifikansi sebesar 0,000. Angka $0,000<0,05$ (nilai alpha) dan t-hitung 4,183 >1,999 (t-tabel) oleh karena itu, Ho ditolak dan menerima Ha. Hal ini berarti terdapat pengaruh antara variabel Gaya Kepemimpinan Demokratik $\left(\mathrm{X}_{2}\right)$ terhadap Kepuasan Kerja Karyawan pada PT Makassar Raya Motor di kota Palu. Hipotesis ketiga dapat diterima.

\section{KESIMPULAN DAN SARAN KESIMPULAN}

Berdasarkan hasil pembahasan penelitian yang telah dikemukakan sebelumnya, maka penulis mengambil beberapa kesimpulan dari hasil penelitian ini sebagai berikut: (1) Kecerdasan Emosional dan Motivasi secara serempak berpengaruh positif dan signifikan terhadap Kinerja karyawan pada PT Palu Golden Hotel . (2) Kecerdasan Emosional secara parsial berpengaruh positif dan signifikan terhadap Kinerja karyawanPT Palu Golden Hotel. (3) Motivasi secara parsial berpengaruh positif dan signifikan terhadap Kinerja karyawan pada PT Palu Golden Hotel.

\section{SARAN}

Berdasarkan pada hasil penelitian serta hal-hal yang terkait dengan keterbatasan penelitian, maka peneliti memberikan saran sebagai berikut: (1) Hasil penelitian ini dapat digunakan sebagai bahan masukan bagi PT Palu Golden Hotel untuk lebih memperhatikan poin-poin kecerdasan emosional, terutama pada aspek pengenalan diri. Dengan adanya pengenalan diri yang mendalam pada karyawan seperti halnya lebih mengetahui kekurang dan batasan pada diri mereka, diharapkan agar tindakan dan keinginan mereka lebih terarah pada kinerja yang lebih baik, tentunya peran atasan disini berfungsi dalam mengawasi dan memediasi lebih dalam para karyawannya. (2) Hendaknya PT Palu Golden Hotel lebih memperhatikan lagi motivasi karyawan terutama pada dimensi kebutuhan rasa aman, yaitu dengan lebih memperhatikan indikator terlindungnya karyawan dari resiko pekerjaan dan keselamat diri karyawan. Dikarenakan sebagian besar karyawan merasa belum cukup terlindung dari resiko pekerjaan yang ada dan mereka masi merasa keselamatan diri mereka dalam bekerja masi belumlah aman. Hal-hal tersebut jika dibiarkan berlarut-larut akan berdampak pada kinerja mereka yang memburuk, dalam hal ini peran manager 
atau atasan menjadi sangat besar,dengan melakukan penilaian kembali lingkungan kerja dan pendekatan kepada karyawan guna mendalami keinginan atau pemenuhan kebutuhan karyawan akan rasa aman dan keselamatan kerja. Sehingga hal tersebut dapat mengoptimalkan semangat mereka untuk terus bekerja. (3) Diharapkan pimpinan dan manajemen PT Palu Golden Hotel memperhatikan kinerja karyawan terutama dalam meningkat usaha karyawan, meningkatkan usuaha karyawan dapat dilakukan dengan melakukan uji kopentensi guna pengembangan sumber daya manusia yang lebih baik. (4) Bagi peneliti berikutnya, diharapkan agar dapat mengembangkan penelitian ini dengan menggunakan variabel lain yang memiliki pengaruh terhadap kinerja karyawan.

\section{REFERENSI}

Bangun, Wilson, 2012, Manajemen Sumber Daya Manusia, PT. Gelora Asara Pratama, Jakarta.

Byars, Rue, 2008, Human Resource Management, Mcgraw-Hill International Edition, New York.

Ghozali, Imam. 2011. Aplikasi Analisis Multivariate Dengan Program SPSS. Ed 6, Badan Penerbit Universitas Diponegoro, Semarang.

Goleman, Daniel, 1997, Kecerdasan Emosional, PT. Gramedia Pustaka Utama, Jakarta.

Goleman, Daniel, 2007, Emotional Intelligence, PT. Gramedia Pustaka Utama, Jakarta.

Hasibuan, Melayu S.P, 2013, Manajemen Sumber Daya Manusia, Bumi Aksara, Jakarta.

Hasibuan, Melayu S.P, 2016, Manajemen Sumber Daya Manusia, Bumi Aksara, Jakarta.

Mangkunegara, AA Anwar Prabu, 2005, Evaluasi kinerja SDM, Refika Aditama, Bandung.

Mangkunegara, AA Anwar Prabu, 2016, Perencanaan Dan Pengembangan Sumber Daya Manusia, Refika Aditama, Bandung.

Nawawi, Hadari. 2005. Manajemen Sumber Daya Manusia untuk Bisnis dan Kompetitif. Yogyakarta: Gadjah Media University Press.

Samsudin, Sadili. 2006. Pembelajaran dalam Implementasi Kurikulum Berbasis Kompetensi. Jakarta: Prenada Media.

Setyaningrum, Utami, Ruhana, 2016, Pengaruh Kecerdasan Emosional Terhadap Kinerja. Jurnal Administrasi Bisnis Vol. 36 No.1 Juli 2016

Solimun, 2002, Multivariate Analysis Struktural Equation Modeling (SEM), Universitas Negeri Malang, Malang.

Sugiyono, 2013, Metode Penelitian Bisnis, Alfabeta, Bandung.

Sunyoto, D. (2012). Teori Kuisioner Dan Analisis Data Sumber Daya Manusia, Yogyakarta: CAPS 